\title{
Secularisation and the rise of immigrant religions: the case of the Netherlands
}

\author{
HANS KNIPPENBERG \\ University of Amsterdam \\ Department of Geography, Planning and International Development Studies
}

\begin{abstract}
Europe and the United States are very different as far as the significance of religion is concerned, both in the private and the public sphere. Whereas autochthon Europe is secularising to a great extent and any growth of religiousness is mainly a matter of immigrants, the United States is the scene of a vivid market of numerous churches, congregations and sects culminating in a high rate of people that belong to a church or religious community and that believe in God. The aim of this paper is to explain this gap between Europe and the United States on the basis of social science theory and theoretical insights derived from (historical) political and cultural geography. It is argued that a different kind of historical political territorialisation (from below in the US versus from above in Europe) in combination with culturally selective settlement (US) is at the centre of the explanation.
\end{abstract}

Key words: geography of religion - political geography - cultural geography - Europe - United States secularisation - territorialisation

\section{Contrasting tendencies}

In a world that is characterised by a growing importance of religion (Berger et al. 1999; Norris \& Inglehart 2004), Europe is the exception. No continent is more secularised now than the one that constructed so many beautiful churches and cathedrals in the past and that was responsible for the spread of Christianity over large parts of the world.

Within Europe, the Netherlands is one of the most secularised of all countries. According to recent surveys 61-66 percent of the population does not adhere to a church or religious community and only 16 percent visit a church or house of prayer on a regular basis (Bernts et al. 2007: 14 and 17; Becker \& De Hart 2006, Annex B3). Christians (Roman Catholics and Protestants) have become a minority of about one third of the population, whereas 6-7 percent of the population adhere non-Christian religions (Islam, Hinduism, Buddhism, Judaism). In the last half a century, the Netherlands witnessed a major transformation of its religious landscape and has become the scene of very contrasting tendencies as far as religion is 
concerned: secularisation to a very high level and the growth of new religious communities, mostly consisting of immigrants with both Christian and nonChristian (especially Muslim) backgrounds (Knippenberg 2005). Hundreds of Christian church buildings and Jewish synagogues were allocated another nonreligious purpose (as dwellings, cultural centres, shops, museums, et cetera), or were simply demolished. On the other hand, one-third of the church buildings that were sold were transferred to another church organisation, mostly Christian, such as Pentecostal or Eastern Orthodox (Van Daalen 1998); in the same period around 433 mosques were established, mostly in already existing buildings, but more recently also in new built ones (see for instance Figure 3).

The aim of this paper is to analyse both contrasting tendencies by a) providing an overview of recent developments in the process of secularisation including some methodological reflections; and b) by going into the rise of new religious communities with special attention to the growth of Islam. Data of the city of Amsterdam will illustrate both tendencies. Theoretical reflections will conclude this paper.

\section{Secularisation}

Defining secularisation or even using the concept is not without problems (Swatos \& Olson 2000); the sociologist Rodney Stark (1999) even proclaimed its death: 'Secularization R.I.P.'. Max Weber (1972; originally 1905) introduced the term and made the connection with the increasing rationality of modern society, with the 'Entzauberung der Welt' (the fading away of the magic) as he called it. The concept became popular in the 1960s and 1970s, when Europe saw a strong decline in religious attachment and religious practice. This decline in 'social religiosity', however, did not necessarily mean a decline in religious believes. According to Luckmann (1967) religion was not disappearing, but underwent a transformation into a privatised form. People no longer accepted the dogmatism and guidelines of the traditional churches, but tended to make up their own religions instead. Religion became characterised as 'invisible' (Luckmann) or as 'believing without belonging' (Davie 1994; 2000).

Already in 1933, the Dutch sociologist or human geographer (he called himself 'sociographer') Kruijt wrote a pioneer study on early Dutch secularisation in which he differentiated between church attachment (kerkelijkheid), church attendance (kerksheid) and religious believes (geloof), which - at least at the individual level covers more or less the above mentioned dimensions of religiosity. When analysing the secularisation of Dutch society in last half of a century I shall present data on all three dimensions. The concept of church will be used in the broad sense of any congregation or religious community, Christian and non-Christian.

Figure 1 shows the rise of secularisation since the end of the 1950s measured by the proportion of the Dutch population that does not adhere to any church or reli- 


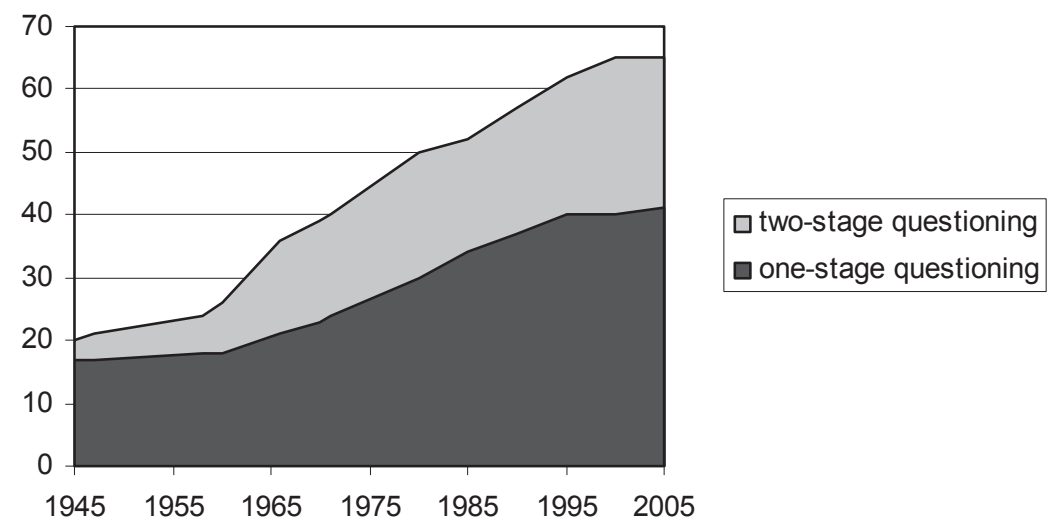

Fig. 1 Non-denominationalism according to CBS and SCP 1945-2005 (percentage of the Dutch population) Source: Estimates on the basis of Becker \& De Hart 2006, 39.

gious community. Although the general trend of increasing secularisation in the meaning of declining religious adherence is clear, the presence of two lines indicates that Dutch statistics on the level of secularisation are very confusing. Both are based on figures gathered by renowned institutions, namely the Dutch Central Bureau of Statistics (CBS) and the Social and Cultural Planning Office (SCP). Both lines show a remarkable increase since the end of the 1950s, but differ considerably concerning the level of secularisation that was reached in the beginning of the twenty-first century. The lower line (CBS) gives a secularisation level of 41 percent in 2004, whereas the upper line (SCP) gives a level of almost 65 percent. How must we explain this difference and what does it mean?

Both institutions measure secularisation in a traditional way by asking people if they adhere to a church or religious community. However, there is an important difference in the way the question was formulated. The CBS used a one-stage questioning, whereas the SCP used a two-stage questioning. One-stage questioning means that one was asked: Which church or religious community do you adhere to? (With separate answer categories for the different denominations plus the category: none). Two-stage questioning means that one was asked: Do you adhere to a church or religious community? (With two answer categories: yes or no). If yes, which church or community do you adhere to? (With separate answer categories for the different denominations). According to Figure 1, the two-stage questioning produces much higher levels of secularisation (and consequently lower levels of adherents of the different churches and religious communities) than the one-stage questioning.

On the basis of two 1998 surveys, in which both kind of questions were asked, the sociologist Becker $(2003 ; 2005)$ has analysed these differences by separating the group that gives different answers on the one-stage and two-stage questioning, from the group of church members and the group of non-denominationalists who 
Tab. 1 Church adherence according to one-stage questioning by church adherence according to two-stage questioning, 1998 (\%)

\begin{tabular}{|l|c|c|c|c|c|c|}
\hline & No Church & $\begin{array}{c}\text { Roman } \\
\text { Catholic }\end{array}$ & $\begin{array}{c}\text { Dutch } \\
\text { Reformed }\end{array}$ & $\begin{array}{c}\text { Orthodox } \\
\text { Calvinist }\end{array}$ & Islam & Others \\
\hline No church & 96 & 27 & 24 & 9 & 29 & 53 \\
\hline Roman Catholic & 2 & 72 & 1 & 1 & & 6 \\
\hline Dutch Reformed & 1 & 0 & 73 & 3 & & 2 \\
\hline Orthodox Calvinist & 0 & & 1 & 79 & & 6 \\
\hline Islam & & & & & 71 & \\
\hline Others & 0 & 0 & 1 & 8 & & 33 \\
\hline Total & 100 & 100 & 100 & 100 & 100 & 100 \\
\hline
\end{tabular}

Source: Becker 2003: 14; Becker 2005: 66.

Tab. 2 Belief issues of church members, "inconsistents", and non-church members 1998 (\%)

\begin{tabular}{|l|l|c|c|c|}
\hline \multicolumn{2}{|l|}{} & Members & Inconsistents & Non-Members \\
\hline Belief in: & Life after death & 81 & 69 & 33 \\
\hline & heaven & 79 & 52 & 15 \\
\hline & hell & 48 & 23 & 6 \\
\hline & religious miracles & 65 & 47 & 14 \\
\hline & a personal God & 61 & 31 & 5 \\
\hline Regards self as: & Atheïst & 0 & 4 & 41 \\
\hline & Agnost & 3 & 8 & 23 \\
\hline Belief in: & Higher power & 9 & 28 & 23 \\
\hline & God, but sometimes doubt & 35 & 36 & 12 \\
\hline & Unconditionally in God & 54 & 24 & 2 \\
\hline Church visit & At least once a month & 57 & 6 & 1 \\
\hline & A few times a year & 23 & 18 & 6 \\
\hline & Never & 20 & 76 & 93 \\
\hline
\end{tabular}

Source: Becker 2003: 18; Becker 2005: 68.

gave the same answer on both types of questions. Let us call the group that gave different answers the 'inconsistents'. The differences vary according to denomination (see Table 1). Small differences ( 9 percent more answering no in a two-stage questioning) are shown for orthodox Calvinist denominations (Gereformeerden): only 9 percent of those who adhere to an orthodox Calvinist church according to a one-stage questioning, said having no denomination in reply to a two-stage questioning. Bigger differences are shown for the Dutch Reformed (23 percent more answering no), Roman Catholics (27 percent more answering no) and Muslims (29 percent). The biggest difference (53 percent) shows up for the remaining denominations and religious communities.

Table 2 summarises the religious beliefs and practises of the three groups: those adhering to a church or religious community in both types of questioning (in short the members), those who do not adhere to a church or religious community in both types of questioning (the non-members), and finally those who adhere to 
a religious community in the one-stage questioning, but do not adhere in the twostage questioning (the inconsistents). Concerning their religious beliefs, the group of inconsistents proves to be a kind of in-between group; their religiosity lies between the group of members and the group of non-members. Concerning religious practise (measured by church attendance), the inconsistents resemble more the non-church members than the church members. Almost all non-members and the large majority of the inconsistents never visit a church or other religious meeting.

It seems fair to assume that many of the respondents interpreted the one-stage questioning as a question on formal church membership (i.e. the church where one was baptised) and the two-stage questioning as a question on which church one would like to adhere to. It is also clear that not adhering to a church or religious community does not mean that one does not believe. One third of the non-members and even 69 percent of the inconsistents believe in a life after death. The belief in a paradise is considerably more popular than the belief in hell. 14 percent of the non-members and 60 percent of the inconsistents believe in God, be it sometimes with doubt. Only 41 percent of the non-members consider themselves as atheist and 23 percent as agnostic. So, the three classical dimensions of religiosity (religious belonging, religious practise, and religious belief) are at least partly independent from each other.

However, the data in Table 2 concern the level of religiosity, but say nothing about the process of secularisation. Therefore, Table 3 is constructed in order to show light on the changes in religious practise and beliefs in the last half a century.

The general trend is a declining religious belief, although the belief in life after death seems increasing in the 1990s. In 194780 percent of the population believed in God, in 2001 only 58 percent did. From the 1960s onwards, the practise of regular church visit is declining too. Only 14 percent of the Dutch population said in 2001 that they visited the church or a religious meeting at least once a week. In 1960 this was 43 percent. These figures come from the World Values Survey. Other sources (Doorn \& Bommeljé 1983; Knippenberg \& De Vos 1991) provide even lower figures for the 1980s. The most recent survey (Bernts et al. 2007: 218) gives the somewhat higher figure of 16 percent in 2006, but was based on a slightly different question (do you visit a church or other religious meeting on a regularly ba-

Tab. 3 Religious belief 1947-2001 and religious practise 1960-2001 (\%)

\begin{tabular}{|l|c|c|c|c|c|c|}
\hline & $\mathbf{1 9 4 7}$ & $\mathbf{1 9 6 0}$ & $\mathbf{1 9 6 8}$ & $\mathbf{1 9 8 1}$ & $\mathbf{1 9 9 0}$ & $\mathbf{2 0 0 1}$ \\
\hline Belief in God & 80 & & 79 & 64 & 61 & 58 \\
\hline Belief in life after death & 68 & & 50 & 41 & 39 & 47 \\
\hline Attending church once a week or more & & 43 & $41^{*)}$ & 26 & 20 & 14 \\
\hline
\end{tabular}

*) 1970

Sources: Norris \& Inglehart 2004, 72 (church visit 1970), 74 (church visit 1981-2001), 90 (belief in God), 91 (belief in life after death); Faber \& Ten Have 1970 (church visit 1960). 
Tab. 4 Church attendance according to denomination, 1970-2003 (percentage of church members)

\begin{tabular}{|l|c|c|c|c|c|}
\hline & $\mathbf{1 9 7 0}$ & $\mathbf{1 9 8 0}$ & $\mathbf{1 9 9 1}$ & $\mathbf{2 0 0 0}$ & $\mathbf{2 0 0 4}$ \\
\hline Roman Catholic & 71 & 47 & 30 & 20 & 19 \\
\hline Dutch Reformed & 50 & 36 & 43 & 35 & 46 \\
\hline Orthodox Calvinist (Gereformeerd) & 89 & 77 & 73 & 57 & 63 \\
\hline
\end{tabular}

Source: Becker \& De Hart 2006: Annex B3.

Recorded is the percentage of the church members who visit church at least one in the two weeks.

Tab. 5 The decline of the Roman Catholic Church in the Netherlands, 1980-2004

\begin{tabular}{|l|r|r|r|r|}
\hline & $\mathbf{1 9 8 0}$ & $\mathbf{1 9 9 0}$ & $\mathbf{2 0 0 0}$ & \multicolumn{1}{c|}{$\mathbf{2 0 0 4}$} \\
\hline Number of baptisms & 55,900 & 51,100 & 42,400 & 34,600 \\
\hline Number of first Communions & 74,200 & 46,300 & 44,600 & 38,500 \\
\hline Number of church marriages & 28,100 & 18,600 & 10,700 & 6,800 \\
\hline Number of church visitors & $1,227,100$ & 728,000 & 438,700 & 348,800 \\
\hline Number of active priests & 3,374 & 2,138 & 1,242 & 1,013 \\
\hline Number of 'pastoral workers' & 302 & 543 & 783 & 797 \\
\hline
\end{tabular}

Source: Becker \& De Hart 2006: 35.

sis?). We also must keep in mind that the frequency of actual church visiting is probably lower, since it is a well-known fact that survey respondents in general overestimate their church visit.

The decline in religious practise varied according to the kind of church involved. Table 4 provides data of the main churches. Church attendance of Roman Catholics diminished spectacularly: from 71 percent in 1970 to only 19 percent in 2004. The Roman Catholic Church declined in other respects as well, for instance in the number of baptisms, first Communions, church marriages, and active priests (Table 5). In 24 years the number of active priests declined from 3,374 to 1,013, which was only partly compensated by an increase in the number of so-called 'pastoral workers'.

In 1970 and 2004, the orthodox Calvinists (Gereformeerden) were the most frequent church visitors, but their church attendance declined, nevertheless. The smallest changes occurred among the Dutch Reformed. This unexpected outcome can be explained by the fact that the composition of the Dutch Reformed changed in a more orthodox direction. The more liberal members left the church, whereas the 'right wing' (Gereformeerde Bond) became more important (Smelik 2006).

In sum, in the last fifty year, the Dutch population has undergone a rapid secularisation. For the first time in history church adherents became a minority and regular church attendance declined to one seventh of the population. Less declining was personal religious belief. Still, the Dutch nation now believes less in God and in notions as paradise and hell, than they did half a century ago. So, there was secularisation in all the three dimensions mentioned in the beginning of this paper: church adherence; church practice; and religious belief. 


\section{The geography of secularisation}

Where do the secularised Dutchmen live? Unfortunately, there are no Dutch censuses any more; the last one was in 1971. Consequently, data on the religious composition of the Dutch municipalities are lacking. Data on religion come from large surveys. Figure 2 shows the regional differences in the level of secularisation based on CBS surveys with one-stage questioning in the 2000-2002 period. There are no recent figures for the different regions based on two-stage questioning. The spatial units are the so-called COROP-regions, a kind of nodal regions constructed for policy reasons. In the CBS surveys used here, 40.7 percent of the Dutch population does not adhere to any kind of church or religious community. The two lowest classes in the map represent the regions below that total population figure; the two highest classes have percentages above that total population figure.

The highest percentages are found in the West and the North, the lowest in the South and the middle of the country. This geographical distribution partly reflects the centuries-old different distribution of Roman Catholics and Protestants. In line

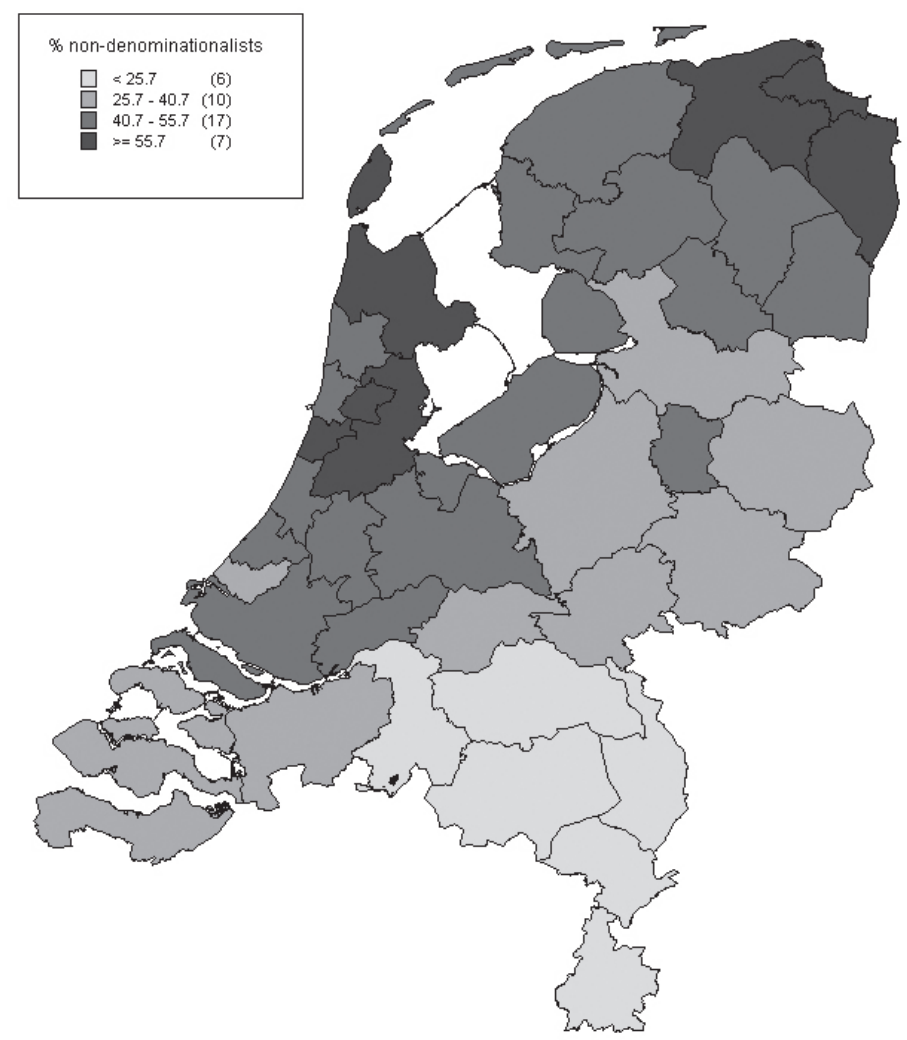

Fig. 2 Percentage of non-denominationalists per COROP region in 2000-2002 Data source: CBS Statline. 
with the classical secularisation thesis (Bruce 2002), Protestants are more secularised than Roman Catholics. The relatively strong Roman Catholic 'pillar' prevented secularisation for a long time. The same holds true for the adherents of the orthodox Calvinist (Gereformeerde) churches with their strong social control. Consequently the living areas of the Roman Catholics (that is the Southeast of the country) and the Dutch Bible Belt (from the Southwest province of Zeeland to the Northeast province of Friesland), where the orthodox Calvinists live, are the regions with percentages below the general Dutch level (Knippenberg 2005).

The most secularised regions are found in the West and the North. The North was the region where already in the last quarter of the nineteenth century socialism gained strength and functioned as a kind of alternative religion for those who suffered from the class contrasts between the rich independent farmers and their poor agricultural labourers. The North, the provinces of Groningen and Drenthe and the Southeast of Friesland, still have relatively high proportions of leftwing voters at Parliamentary elections. The province of North Holland was traditionally dominated by a liberal kind of Protestantism, and the Zaanstreek was already around 1900 the most secularised region in the country, due to industrial class contrasts. Apart from the influence of socialism, urbanisation was a major incentive for secularisation. The West is dominated by the Randstad, that is the urban zone including the cities of Amsterdam, Rotterdam, Den Haag, Utrecht, Haarlem, and Leiden. The northern part of the Randstad (for instance Amsterdam and Haarlem) is more secularised than the southern part (for instance Rotterdam). In the past the southern part attracted more immigrants from the Bible Belt, whereas the northern part attracted immigrants from Friesland and the province North-Holland.

\section{The rise of immigrant religions: the case of Amsterdam}

However, the Randstad also is the scene of the second major feature of the current Dutch religious landscape: the rise of religious plurality as a consequence of large-scale immigration from different parts of the world. In order to illustrate both features in connection, I shall first present some data on the city of Amsterdam.

During the 1947 Census, Amsterdam had 803,847 inhabitants. 45 percent of them were secularised, 27 percent adhered one of the main Protestant churches, 23 percent were Roman Catholic, 0.7 percent were Jewish and 4 percent adhered to another church or religious community (Table 6).

More than half a century later, in 2001, according to a survey held by the municipal statistical office the situation was as follows $(\mathrm{O}+\mathrm{S} 2001)$. The total population was diminished to 734,000 people due to sub-urbanisation and a declining birthrate in the 1960s and 1970s. In 1990, Amsterdam counted only 695,000 people, but since then the Amsterdam population is growing again due to a migration surplus and an excess of births over deaths. The most recent population figure is 743,027 (January 2006; Amsterdam in cijfers 2006: 16). In the survey the definition of reli- 
Tab. 6 Amsterdam population according to religion in 1947

\begin{tabular}{|l|c|c|}
\hline & number & \% \\
\hline Roman Catholic & 187,458 & 23.3 \\
\hline Dutch Reformed & 152,564 & 5.0 \\
\hline Orthodox Calvinist (Gereformeerd) & 40,018 & 2.1 \\
\hline Lutheran & 16,816 & 1.1 \\
\hline Mennonite & 8,517 & 3.7 \\
\hline Other denomination (mainly Protestant) & 29,850 & 0.7 \\
\hline Jewish & 5,269 & 45.2 \\
\hline No denomination & 363,355 & 100.0 \\
\hline Total population & 803,847 & \\
\hline
\end{tabular}

Source: Census 1947.

Tab. 7 Amsterdam adult population according to religion in 2001

\begin{tabular}{|l|c|}
\hline & $\mathbf{\%}$ \\
\hline Muslim & 14 \\
\hline Roman Catholic & 10 \\
\hline Protestant & 7 \\
\hline Jewish & 1 \\
\hline Other religion & 9 \\
\hline No religion & 56 \\
\hline Unknown & 3 \\
\hline Total & 100 \\
\hline
\end{tabular}

Source: O + S 2001 .

gion was broader than in the Census. Also ideologies such as humanism, anthroposophism, and New Age were included. Moreover, the figures only concern the adult population. Therefore, these figures are not entirely comparable with the Census figures. Still, these figures give some indication of the changes since 1947 (see Table 7).

In 200156 percent of the Amsterdam population did not adhere to any church or religious community. Only 17 percent adhered to one of the Christian churches (in 1947, that was 60 percent!). No less than 14 percent was Muslim, 1 percent Jew and 9 percent adhered to another religious community, for instance Hindu, Buddhist, or New Age. There was no linear development in secularisation between 1947 and 2001. In 198679 percent of the Amsterdam population did not adhere to any church or religious community (Doorn \& Bommeljé 1987: 31). After that, Amsterdam has become more religious, be it not more Christian.

Still, there was also a rise in 'new' branches of Christianity. In 2002, a total of 352 churches and other houses of prayer were counted of which no less than 40 percent was labelled as new Christian churches (CD-Rom Gebedshuizen 2002). That is more than all the traditional Protestant and Roman-Catholic churches together. Pentecostal and Evangelical congregations in particular are growing explosively. 


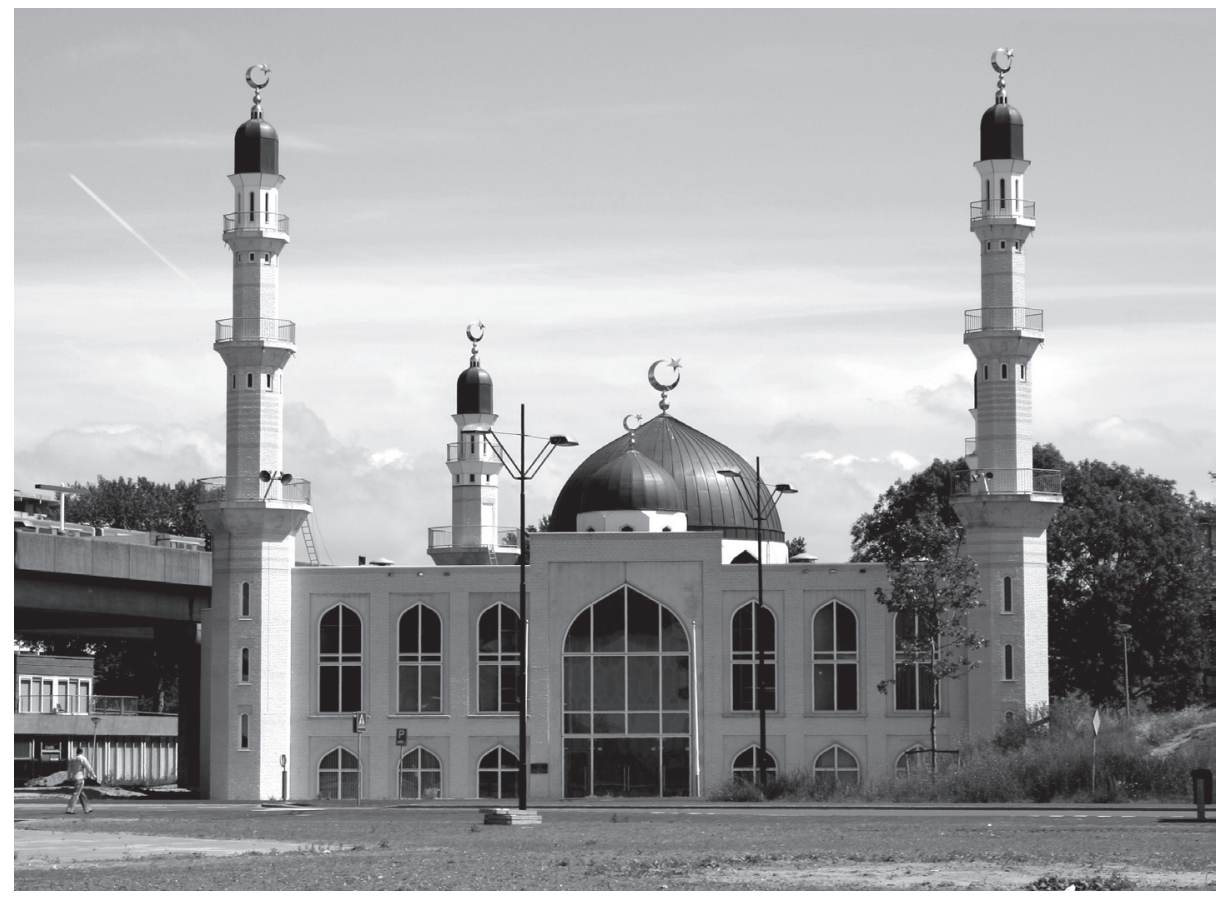

Fig. 3 Grand mosque Taibah in Amsterdam-Southeast (Bijlmermeer)

(Photo Leo de Klerk)

Lack of church buildings and financial resources force these communities to meet each other in alternative places for their religious services, such as community centres, schools and garages.

Most striking is the growth of Islam. In 1977, the first mosque was established (a Tuskish mosque in the Nieuwezijds Kapel at the Rokin); in 2002, already 39 mosques were counted and since then the number has increased to at least 46 ones apart from Muslim houses of prayer in hospitals, prisons, universities, schools, buildings of Muslim organisations, et cetera (Bosatlas 2007: 369). Most mosques started in existing buildings such as private homes, schools and commercial properties, but recently gradually more new mosques were built with one of more minarets, such as the grand mosque Taibah in Amsterdam-Southeast (Bijlmermeer) with even four minarets (Figure 3). Further, there were smaller numbers of Buddhist and Hindu temples, Jewish synagogues, and Eastern Orthodox churches.

It will be clear that immigration is the main cause of the growth of this religious plurality. The first immigrants came from China and the former Netherlands Indies in the 1940s and 1950s. That immigration also brought the first small group of Muslims from the South-Moluccas (a group of isles in the East of the Indonesian archipelago) to the Netherlands. From the 1950s onwards people from Suriname and the Netherlands Antilles came to the Netherlands for schooling or work. After 
Tab. 8 Amsterdam population according to origin, 2006

\begin{tabular}{|l|r|c|}
\hline Country of origin & number & \% \\
\hline Netherlands & 382,746 & 51.5 \\
\hline Suriname & 69,645 & 9.4 \\
\hline Morocco & 65,426 & 8.8 \\
\hline Turkey & 38,337 & 5.2 \\
\hline Indonesia (incl. Dutch Indies) & 26,805 & 3.6 \\
\hline Germany & 16,905 & 2.3 \\
\hline Neth. Antilles (incl. Aruba) & 11,360 & 1.5 \\
\hline Ghana & 10,330 & 1.4 \\
\hline United Kingdom & 9,312 & 1.3 \\
\hline United States of America & 5,996 & 0.8 \\
\hline (former) Yugoslavia & 5,371 & 0.7 \\
\hline Egypt & 5,348 & 0.7 \\
\hline Pakistan & 5,129 & 0.7 \\
\hline Other non-Western & 22,789 & 3.1 \\
\hline Other Western & 67,528 & 9.1 \\
\hline Total & 743,027 & 100.0 \\
\hline
\end{tabular}

Source: Amsterdam in cijfers 2006.

the independence of Suriname in 1975 many Surinamese settled in Amsterdam, adhering to Christian, Hindu, and Muslim religions. In the 1960s and 1970s Mediterranean migrants came to the Netherlands for economic reasons, first Italians, Spaniards, Yugoslavs and Greeks, later predominantly Turks and Moroccans, followed in the 1980s and 1990s by their families. That was the start of the explosive increase of the number of Muslims. More recently refugees from very different parts of the world, including Asia, Latin America and Africa, and seeking for asylum broadened the ethnic and religious spectrum considerably. In 2006, about 176 different nationalities were living in Amsterdam and almost half of the Amsterdam population was of non-Dutch origin (see Table 8). In 2006, 10 percent came from Suriname, 8 percent from Turkey, 5 percent from Morocco, 2 percent from the Netherlands Antilles, 2 percent from Southern European countries, 10 percent from other non-Western countries, and 10 percent from other industrialised countries.

\section{Immigrant religions and churches}

The case of Amsterdam illustrates the general Dutch trend of rising immigrant religions of which Islam, Hinduism and 'new' evangelical-charismatic branches of Christianity are the most important. According to recent (2004/2005) estimates 944,000 Muslims and 99,000 Hindus are living in the Netherlands, corresponding with 5.8 and 0.6 percent of the population respectively (Becker \& De Hart 2006: 34). The rich variety of Pentecostal and Evangelic communities hosts about 81,000 followers. The growth of Islam is the most striking change in the Dutch religious 


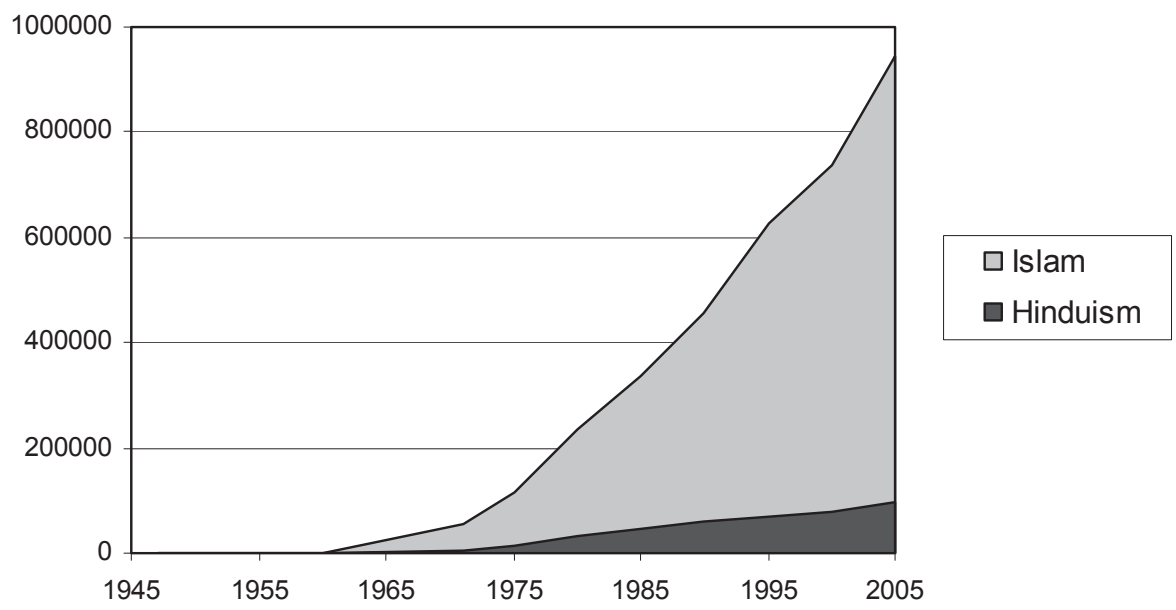

Fig. 4 The rise of Islam and Hinduism 1945-2005 (number of adherents)

Source: Census 1947/1960/1971; Becker \& De Hart 2006, 34.

landscape (see Figure 4). That growth was not only caused by immigration, but also by relatively high fertility levels (Prins 1994).

The first mosques in the Netherlands were established in The Hague (Pakistani) in 1955 and in the Frisian village of Balk (Moluccan) in 1956 (Landman 1992: 30-35). Now (2007), there are 433 mosques in the Netherlands (Bosatlas 2007: 369). Most of them are of Turkish origin (about 223), followed by about $150 \mathrm{Mo-}$ roccan mosques and about 36 Surinamese mosques. Originally, mosques were established in existing buildings, but since 2000, existing mosques were replaced by new built ones, especially in the big cities, such as the two minaret Turkish Mevlana mosque in Rotterdam (2001) and the already mentioned four minaret Taibah mosque in Amsterdam (2005). The most recent estimates count 46 mosques in Amsterdam, 34 in Rotterdam, 33 in The Hague and 14 in Utrecht (Ibidem). The Dutch Central Bureau of Statistics has made estimates of the number of Muslims in different parts of the country on the basis of data concerning the ethnic origin of the people. Figure 5 map these data.

Muslims prove to be highly concentrated in the urban areas in the west of the country: the big cities and their surroundings. In the metropolitan region of Amsterdam 13 percent of the population is Muslim. The region of The Hague hosts 11 percent Muslims, and Rijnmond, i.e. the region of Rotterdam 10 percent. The province of Utrecht and the polders of Flevoland, where the overspill from Amsterdam and other parts of the Randstad is concentrated, also have percentages above the country figure of 5.7 percent. The rest of the country has percentages below the country figure. Some old industrial areas such as Twenthe and North Brabant are just below the country figure. The lowest proportions of Muslims are found in the North (the provinces of Groningen, Friesland and Drenthe) and the Southwest (the 


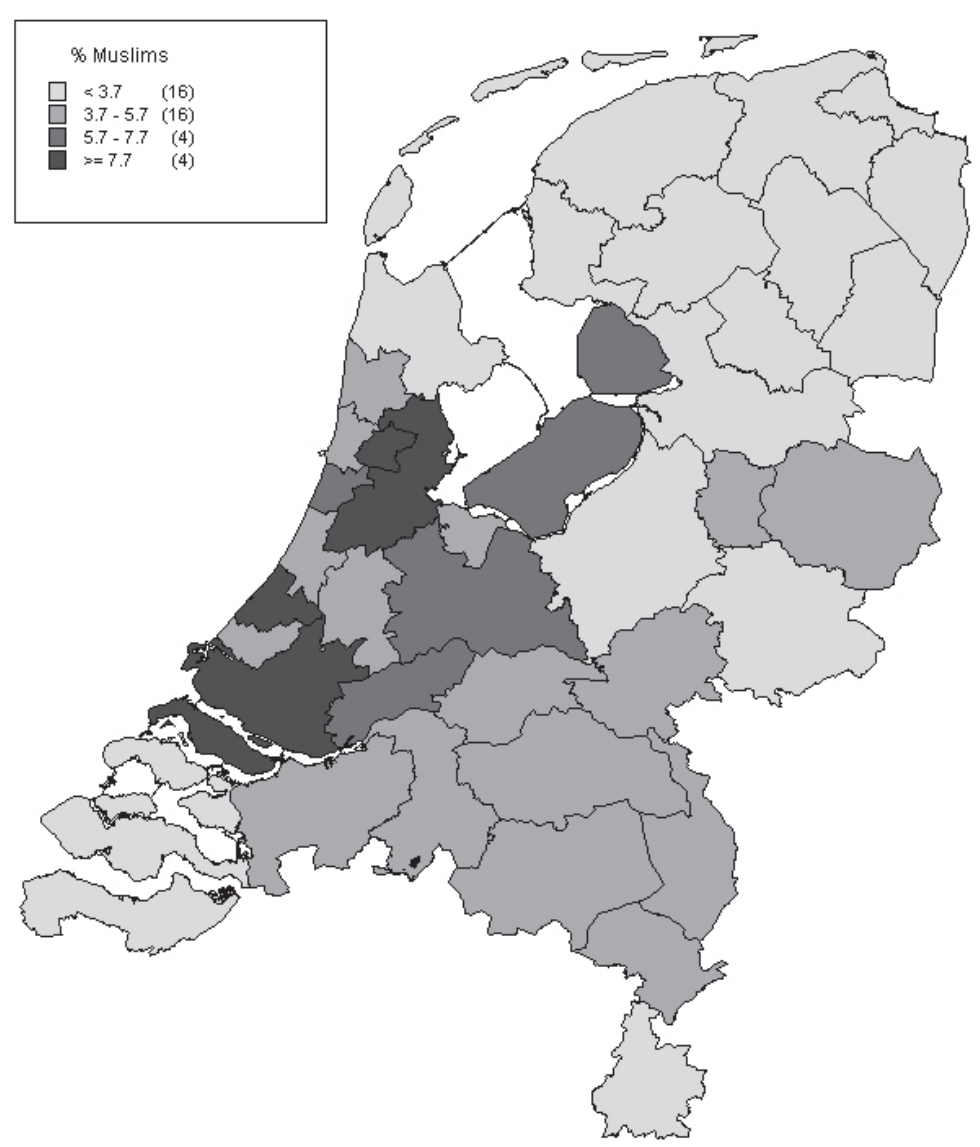

Fig. 5 Percentage of Muslims per COROP region in 2003

Data source: CBS Statline.

province of Zeeland). In the North as a whole, Muslims make up not more than 2 percent of the population. That had much to do with the less attractive economic conditions in these areas.

Immigrants also came from Christian countries and gave rise to a rich variety of Christian churches of foreign background. In general three main types of Christian migrant churches or religious communities can be distinguished (Van den Broek 2004; Arnts 2006). First, there are the churches of the 'old' migrants and refugees, such as the Walloon Church, originally the church of the Huguenots, i.e. the protestant refugees from France following the Revocation of the Edict of Nantes in 1685; the churches from the former Dutch colonies Indonesia (Dutch Indies) and Suriname (Evangelische Broedergemeenten); and the several Eastern-Orthodox Churches of migrants from Russia, Serbia, Greece, Syria, Bulgaria, Romania, Armenia, and Georgia. The second type includes the churches for foreigners, who are 
living or visiting the Netherlands temporarily, such as the Anglican Church, Presbyterian Churches (English or Scots), the Fins Church and several 'seamen churches' (Swedish, Norwegian, Danish). These churches are often part of churches abroad. The most dynamic branch of immigrant churches is the third type, which consist of churches and religious communities meant for immigrants and refugees from Africa, Asia and Latin-America. Usually, these communities are shaped around a religious leader, who wanted to establish a church, often of a Pentecostal or Evangelical nature. A special branch of Roman Catholicism include the so-called ethnic or language parishes. Formally, these parishes are part of the Roman Catholic Church. They have been established because Roman Catholic immigrants and refugees have many problems in joining the existing Dutch parishes. A growing number of foreign priests takes care of these immigrant communities.

\section{Do immigrants secularise?}

In the past, the fully integrated 'old' immigrants in Dutch society, such as the Walloon Reformed from France, Lutherans from Scandinavia, Germany and Austria, and Jews from the Iberian Peninsula (Sephardim) and Eastern Europe (Ashkenazim), secularised when Dutch society as a whole secularised (Knippenberg 1992). The question rises, will the more recent immigrants secularise as well? Second generation Muslims and Hindus in particular are interesting in this respect, since they were born in the Netherlands, went to Dutch schools and were confronted with the dominant Dutch individualistic, rationalistic and secularised culture from the start.

Unfortunately, reliable figures on the secularisation of Muslims and Hindus are missing. So, the figures presented here must be treated with some caution. A first indication provides Table 1. 29 percent of the Muslims according to a one-stage type of questioning said no religion when asked according to a two-stage type of questioning. The figures in Table 9 are derived from a survey held by the Dutch Social and Cultural Planning Office (Sociaal en Cultureel Planbureau) in 1998.

According to these figures, the level of secularisation among Turks and Moroccans is very low. Only a small minority answered that they did not have a religion. Even the second generation is hardly secularised: no more than $5 \%$ of the Turks and Moroccans have no religion (any more). In sharp contrast, the $19 \%$ of the first generation of Surinamese and $42 \%$ of the second generation has no religion (any more). That concerns the Surinamese Muslims too. Only 6\% of the second generation is Muslim, whereas $10 \%$ of the first generation is.

However, there are some methodological problems with this survey. They are coming from a survey among households and often all the members of these households have been questioned in the presence of the head of the household. In some cases the head of the household even filled in the questionnaires of all the other members. So, there is probably some bias in the results presented in the table. 
Tab. 9 Secularisation of Turks, Moroccans and Surinamese in 1998 (in \%)

\begin{tabular}{|c|c|c|c|}
\hline & \multicolumn{2}{|c|}{ Generation } \\
\hline & & First & Second \\
\hline \multirow{3}{*}{ Turks } & Islam & 95 & 94 \\
\hline & No religion & 4 & 4 \\
\hline & Other & 2 & 2 \\
\hline \multirow{3}{*}{ Moroccans } & Islam & 98 & 95 \\
\hline & No religion & 2 & 5 \\
\hline & Other & 0 & 0 \\
\hline \multirow{5}{*}{ Surinamese } & Islam & 10 & 6 \\
\hline & Christian & 43 & 30 \\
\hline & Hindu & 26 & 20 \\
\hline & No religion & 19 & 42 \\
\hline & Other & 2 & 1 \\
\hline
\end{tabular}

Source: Becker \& De Wit 2000, 18.

Tab. 10 Secularisation of Turkish, Moroccan and Surinamese pupils in 1996 (in \%)

\begin{tabular}{|l|l|c|}
\hline \multirow{4}{*}{ Turks } & Islam & 81 \\
\cline { 2 - 3 } & No religion & 12 \\
\cline { 2 - 3 } & Other & 7 \\
\hline \multirow{4}{*}{ Surinamese } & Islam & 88 \\
\cline { 2 - 3 } & No religion & 6 \\
\cline { 2 - 3 } & Other & 7 \\
\hline \multirow{5}{*}{} & Islam & 7 \\
\cline { 2 - 3 } & Christian & 39 \\
\cline { 2 - 3 } & Hindu & 18 \\
\cline { 2 - 3 } & No religion & 25 \\
\cline { 2 - 3 } & Other & 10 \\
\hline
\end{tabular}

Source: Becker \& De Wit 2000, 18.

Therefore, Table 10 is constructed which presents the outcomes of another survey among pupils. These 12-23 years old pupils filled in their questionnaires in their classrooms during school-time. So, one could expect that they are less influenced by the norms of their parents.

The results of the survey among pupils show higher Turkish and Moroccan levels of secularisation, although far removed from the levels of Dutch autochthons. So, there is some indication, that the general secularisation process in Dutch society also affects the younger generations of Muslims of Turkish and Moroccan origin. A general but limited secularisation trend among (first and second generation) immigrants of Turkish and Moroccan origin was also found in a review study published in 2004 and based on a comparison of 1998 and 2002 surveys (Phalet \& Ter Wal 2004). The level of secularisation still remains low. In 20025.3 percent of the Turkish immigrants and 2.6 percent of the Moroccan immigrants had no religion. 
Tab. 11 Secularisation of pupils according to ethnic identification in 1996 (in \%)

\begin{tabular}{|l|l|r|r|r|}
\hline \multirow{4}{*}{} & \multirow{2}{*}{$\mathbf{N}$} & \multicolumn{2}{c|}{ Ethnic identification } \\
\cline { 3 - 5 } & & & Origin & Dutch \\
\hline \multirow{4}{*}{ Turks } & 183 & 66 & 34 \\
\cline { 2 - 5 } & Islam & & 97 & 50 \\
\cline { 2 - 5 } & No religion & & 3 & 30 \\
\cline { 2 - 5 } & Other & & 1 & 20 \\
\hline \multirow{4}{*}{ Moroccans } & & 108 & 73 & 27 \\
\cline { 2 - 5 } & Islam & & 95 & 71 \\
\cline { 2 - 5 } & No religion & & 1 & 14 \\
\cline { 2 - 5 } & Other & & 3 & 14 \\
\hline \multirow{4}{*}{ Surinamese } & & 202 & 53 & 47 \\
\cline { 2 - 5 } & Islam & & 9 & 5 \\
\cline { 2 - 5 } & Christian & & 38 & 42 \\
\cline { 2 - 5 } & Hindu & & 25 & 10 \\
\cline { 2 - 5 } & No religion & & 17 & 34 \\
\cline { 2 - 5 } & Other & & 11 & 10 \\
\hline
\end{tabular}

Source: Becker \& De Wit 2000, 21.

The 1996 survey among pupils further showed that there was some connection with their ethnic identity, as can be demonstrated in Table 11. Since the outcomes of Table 11 are based on relatively small numbers, one should consider these results with some caution. Nevertheless, these outcomes all tend to the same conclusion, that identification with the Dutch nation (in contrast to ethnic identification with the nation of origin) positively correlates with the level of secularisation. This identification with the Dutch nation is relatively strong among the Surinamese people: almost half of the Surinamese pupils feel themselves Dutch in the first place. One third of the Turkish and a quarter of the Moroccan pupils identify themselves as Dutch.

\section{Conclusions and some theoretical reflections}

Large-scale secularisation at the cost of the traditional Protestant and RomanCatholic churches on the one hand and the rise of immigrant religions, notably Islam, Hinduism and new charismatic Christian religions, on the other hand, are the main features of the changing religious landscape in the Netherlands since the 1950s. The urban areas, the city of Amsterdam in particular, are pre-eminently the places where both tendencies come together. Secularisation and religious pluralisation are not only important features of the Dutch religious landscape, but also of the European religious landscape in general (Henkel \& Knippenberg 2005).

There has been much debate on different theories that want to explain the process of secularisation in the West (see for instance Swatos \& Olson 2000; Wunder 
2005). First there is the classic secularisation paradigm, whether rooted in Weberian claims about the rationality of belief systems, or on Durkheimian arguments of functional differentiation. Bruce (2002) has convincingly elaborated a recent version of this classic secularisation paradigm. The main attacks on this secularisation paradigm came from American social scientists that were confronted with the high level of religiosity and religious practise in the United States, which seemed contradictory to the secularisation theory, that predicted an ongoing process of secularisation in modern societies. They launched their religious market theory, which in fact assumed a constant need for religion, so, that the level of religiosity and religious attachment and participation depends on the supply-side of religion. In short, the market-theory predicts that religious attachment, participation and belief will increase with greater religious plurality and with less state regulation of religious institutions (see for instance Finke \& Stark 1988; Stark \& Iannacone 1994; Stark 1999). The massive Dutch secularisation, whether measured as the decline of organised religion or as subjective religiosity, in fact supports the classic secularisation paradigm. Any state deregulation of religion (see for instance Knippenberg 2006) and increases in religious pluralism that occurred since the $1950 \mathrm{~s}$ did not have the theoretical effects that the market theories predicted. Consequently, the Dutch case casts serious doubt on the explanatory power of the supply-side theories (see also Lechner 1996).

In their recent and very inspiring cross-country analysis of the growth and decline of religion in the world, the well-known American political scientists Norris and Inglehart (2004) came to a comparable conclusion. Their quantitative analysis based on comparable data bases, such as the World Value Surveys, the UN Human Development Reports, World Development Indicators of the World Bank, and Freedom House data, provided no empirical evidence, what so ever, for the religious market or supply-side theory of secularisation (see also Wunder 2005: 147-190). They reject the assumption that everywhere, in all parts of the world, there would be a constant need for religion. On the contrary, in the more developed parts of the world, that need is declining, which supports the secularisation paradigm, in other parts of the world, however, that need is increasing or have always been on a very high level.

To explain the differences between the nations in the world, they have formulated a new theory, what they call the Theory of Existential Security and Secularisation. Central is the hypothesis that the conditions that people experience in their formative years have profound impact upon their cultural values. Growing up in societies, in which survival is uncertain, is conducive to a strong emphasis on religion; conversely, experiencing high levels of existential security throughout one's formative years, reduces the subjective importance of religion in people's lives.

This hypothesis can also be applied to the case of the Netherlands. The rise of the Dutch welfare state, from the nineteenth century onwards, but in the post-World War II period in particular, has brought a societal and individual level of existential 
security that was unprecedented. In the same period, the secularisation of Dutch society, both concerning religious belonging, practise and belief, reached high levels too. That seems consistent with the Norris/Inglehart theory. Generally speaking, the only religious increase was a consequence of the influx of immigrants. That is pre-eminently the group of people that has faced existential insecurity, both in their countries of origin, and also in the Netherlands, where they had to find their way in a country so different from what they were used to. So, my preliminary conclusion is that both tendencies of secularisation and the rise of immigrant religions are consistent with this theory of existential security and secularisation. So is the (limited) secularisation trend among second generation Surinamese, Turkish and Moroccan immigrants.

Finally, there is a demographic factor involved. The rich nations that faced secularisation, also witnessed a sharp decline of fertility levels in the same period, so that population growth has stagnated or their population is even starting to shrink. Conversely, poor societies with high levels of religiosity still experience rapid population growth. The result of these combined trends is that rich societies are becoming more secular but the world as a whole is becoming more religious (Norris \& Inglehart 2004: 216-217). In some respect the city of Amsterdam is facing a more or less comparable process: the autochthon Dutch part of the population is secularising and shrinking in numbers, but the city as a whole has become more religious not only as a consequence of the immigration of religious newcomers, but also of their relatively high fertility levels.

\section{References}

ARNTS, L. (2006): De migrantenkerken. In: J. Becker \& J. de Hart, Godsdienstige veranderingen in Nederland. Den Haag: Sociaal en Cultureel Planbureau, Annex B3.

BECKER, J. (2003): De vaststelling van de kerkelijke gezindte in enquêtes. Werkdocument 92. Den Haag: Sociaal en Cultureel Planbureau.

BECKER, J. (2005): Church membership investigated (1950-2002). In: E. Sengers (ed.), The Dutch and their gods. Secularization and transformation of religion in the Netherlands since 1950. Hilversum: Verloren, $59-71$.

BECKER, J. \& DE HART, J. (2006): Godsdienstige veranderingen in Nederland. Den Haag: Sociaal en Cultureel Planbureau.

BECKER, J.W. \& DE WIT, J.S.J. (2000): Secularisatie in de jaren negentig. Den Haag: Sociaal en Cultureel Planbureau.

BERGER, P.L. (ed.) (1999): The desecularization of the world. Resurgent religion and world politics. Grand Rapids, Mich.: Eerdmans.

BERNTS, T., DEKKER, G. \& DE HART, J. (2007): God in Nederland 1996-2006. Kampen: Ten Have.

BOSATLAS (2007): Bosatlas van veranderend Nederland. Groningen: Wolters Noordhoff.

BRUCE, S. (2002): God is dead. Secularization in the West. Oxford: Blackwell.

CD-ROM GEBEDSHUIZEN (2002): Gebedshuizen in Amsterdam. Amsterdam: Internationaal Instituut voor Sociale Geschiedenis.

DAVIE, G. (1994): Religion in Britain since 1945. Believing without belonging. Oxford: Blackwell.

DAVIE, G. (2000): Religion in modern Europe. A memory mutates. Oxford: Oxford University Press.

DOORN, P. \& BOMMELJÉ, Y. (1983): Maar ... men moet toch iets wezen. Nieuwe gegevens over ontkerkelijking in Nederland. Utrecht: Humanistisch Verbond. 
DOORN, P. \& BOMMELJÉ, Y. (1987): Ontkerkelijking en verzuiling. Een onderzoek naar de invloed van kerken op publieke middelen in Nederland. Utrecht: Humanistisch Verbond.

FABER, H. \& TEN HAVE, T.T. (1970): Ontkerkelijking en buitenkerkelijkheid in Nederland, tot 1960. Assen: Van Gorcum.

FINKE, R. \& STARK, R. (1988): Religious choice and competition. American Sociological Review 63: 761-766.

HENKEL, R., \& KNIPPENBERG, H. (2005): Secularisation and the rise of religious pluralism. In: H. Knippenberg (ed.), The changing religious landscape of Europe. Amsterdam: Het Spinhuis, 1-13.

KNIPPENBERG, H. (1992): De religieuze kaart van Nederland. Assen: Van Gorcum.

KNIPPENBERG, H. (2005): The Netherlands: Selling churches and building mosques. In: H. Knippenberg (ed.), The changing religious landscape of Europe. Amsterdam: Het Spinhuis, 88-106.

KNIPPENBERG, H. (2006): The changing relationship between state and church/religion in the Netherlands. GeoJournal 67, 317-330.

KNIPPENBERG, H. \& DE VOS, S. (1991): Hedendaags kerkbezoek: de invloed van omgevingsfactoren en individuele kenmerken. Nederlands Theologisch Tijdschrift 45, 46-59.

KRUIJT, J.P. (1933): De onkerkelikheid in Nederland. Groningen: Noordhoff.

LANDMAN, N. (1992): Van mat tot minaret. De institutionalisering van de islam in Nederland. Amsterdam: VU Uitgeverij.

LECHNER, F.J. (1996): Secularization in the Netherlands? Journal for the Scientific Study of Religion 35, 252-264.

LUCKMANN, T. (1967): The invisible religion. The problem of religion in modern society. New York: MacMillan.

NORRIS P. \& INGLEHART, R. (2004): Sacred and Secular. Religion and politics worldwide. Cambridge: Cambridge University Press.

O \& S (2001): Geloven in Amsterdam. Fact Sheet 5. Amsterdam: Bureau voor Onderzoek en Sattistiek.

PHALET, K. \& TER WAL, J. (2004): Moslim in Nederland. Diversiteit en verandering in religieuze betrokkenheid. SCP-werkdocument 106b. Den Haag/Utrecht: Sociaal en Cultureel Planbureau/ Ercomer.

PRINS, C.J.M. (1994): Islamieten en hindoes in Nederland. Herziening van een tijdreeks. CBS Maandstatistiek van de Bevolking 1994-2, 22-27.

SMELIK, J. (2006): Omvang en spreiding van 'gereformeerde-bondsgemeenten' 1973-2003. Documentatieblad voor de Nederlandse Kerkgeschiedenis na 1800 64, 33-59.

STARK, R. (1999): Secularization, R.I.P. Sociology of Religion 60, 249-273.

STARK, R. \& IANNACONE, L.R. (1994): A supply-side reinterpretation of the 'secualarization' of Europe. Journal for the Scientific Study of Religion 33, 230-252.

SWATOS, W.H. \& OLSON, D.V.A. (eds.) (2000): The secularization debate. Lanham: Rowman and Littlefield. (also as Special issue on Secularization of Sociology of Religion 60-3, 1999).

VAN DAALEN, G. (1998): Het tweede leven van de kerk. Hoe religieus goed wordt herbestemd. Agora 14, 4: $10-13$.

VAN DEN BROEK, A.P. (2004): Ieder hoorde zijn eigen taal. Inventarisatie van kerken voor - en van nieuwkomers en migranten in Nederland. Amsterdam: Raad van Kerken/SKIN.

WEBER, M. (1972): Die protestantische Ethik und der Geist des Kapitalismus. In: M. Weber, Gesammelte Aufsätze zur Religionssoziologie. Band I. Tübingen: Mohr, 17-206.

WUNDER, E. (2005): Religion in der postkonfessionellen Gesellschaft. München: Franz Steiner Verlag.

\section{Résumé}

\section{Sekularizace a nárůst významu náboženství přistěhovalců: př́pad Nizozemska}

Pro celosvětový vývoj je charakteristický nárůst významu religií (Berger et al. 1999; Norris \& Inglehart 2004), ale v rámci Evropy se jedná spíše o výjimku. Žádný jiný světadíl není v současné době v takovém pokročilém stavu sekularizace a přitom právě Evropa vybudovala v minulosti mnoho nádherných náboženských staveb (katedrály, kostely atd.) a je odpovědná také za rozšǐřní křest’anství do celého světa.

V rámci Evropy patří Nizozemsko k nejvíce sekularizovaným státům. Podle současných výzkumů 61-66\% obyvatel Nizozemska se nehlásí k žádné církvi nebo náboženské komunitě a pouze 16 procent 
obyvatel navštěvuje církve k pravidelným modlitbám (např. Bernts et al. 2007). Křest’ané se stali menšinou $\mathrm{s}$ podílem méně než jedné třetiny obyvatel a $\mathrm{k}$ tomu ještě okolo $6-7$ procent populace se hlásí $\mathrm{k}$ nekřest’anským náboženstvím (islám, hinduismus, buddhismus a judaismus).

Cílem studie bylo analyzovat dvě kontrastní tendence. Za prvé stanovit přehled současného vývoje procesu sekularizace včetně vybraných metodologických reflexí a za druhé popsat nárůst významu nových náboženských komunit v Nizozemsku se zvláštním zřetelem na islám. Jako modelové území přitom posloužilo město Amsterdam.

Hans Knippenberg University of Amsterdam Department of Geography, Planning and International Development Studies Nieuwe Prinsengracht 130

1018 VZ Amsterdam

The Netherlands e-mail: H.Knippenberg@uva.nl 